\title{
FRONTIER PRODUCTION EFFICIENCY OF CASSAVA CHIPS SMES IN LAMPUNG
}

\author{
Fitriani $^{* 1}$, Bina Unteawati*), Cholid Fatih ${ }^{*}$, and Sutarni*) \\ *) Economics and Business Department, Politeknik Negeri Lampung \\ Jl. Soekarno Hatta Rajabasa Bandar Lampung, Lampung, Indonesia, 35145
}

\begin{abstract}
Strengthening the downstream of the agri-food chain holds a strategic part in enhancing the rural economy. This research was conduct to analyze the frontier production efficiency of cassava chip processing in rural. Then explore the opportunity to develop productivity enhancement of small-scale cassava chips SMEs. The research location referred to the cassava production centre in Lampung, which involved six District regions. Respondent was 60 small-scale cassava industries. Field survey had taken from February to April 2017. Analyzed data designed by the frontier production and binary logistic regression model. The production efficiency value of cassava chips SMEs achieved $61 \%$ on average. The achievement value still less than the optimum efficiency. The cassava chips SMEs still operated at a medium level of technical efficiency. Input combination is not optimum, and technology facilities even limited caused the production output not to reach the manufactured capacity the production run under the capacity production. Scale-up the production capacity is necessary. The introduction of the new technology equipment opens the possibilities in scale-up capacity production. The opportunity to adopt the new cassava processing equipment's strongly was affected by human resources skills and appropriate production equipment. The cassava SMEs technology application is significantly determined by experience and production equipment. Furthermore, the proper linkage between SMEs and university or research agencies is necessary to improve technology adoption. The current microcredit scheme is also vital in provide adequate capital on scale-up production capacity.
\end{abstract}

Keywords: cassava, efficiency, frontier, rural, SMEs

\begin{abstract}
Abstrak: Penguatan rantai nilai produk pangan memiliki peran strategis dalam meningkatkan perekonomian pedesaan. Penelitian ini dilakukan untuk menganalisis efisiensi produksi usaha pengolahan aneka keripik singkong di pedesaan, juga peluang pengembangannya. Lokasi penelitian adalah enam kabupaten sentra produksi ubi kayu di Lampung. Responden adalah 60 industri kecil ubi kayu. Survei lapangan dilakukan dari Februari hingga April 2017. Data dianalisis dengan pendekatan efisiensi produksi frontier dan model regresi logistik. Nilai efisiensi produksi UKM keripik ubi kayu rata-rata mencapai 61\%. Nilai pencapaian masih kurang dari efisiensi optimal. UKM keripik singkong masih beroperasi pada tingkat efisiensi teknis yang rendah. Kombinasi input yang tidak optimal, bahkan fasilitas teknologi yang terbatas menyebabkan output produksi tidak mencapai kapasitas optimal produksi berjalan di bawah kapasitas produksi. Upaya peningkatan kapasitas produksi diperlukan. Penggunaan teknologi produksi baru dapat meningkatkan kapasitas produksi pelaku usaha. Adopsi teknologi peralatan pengolahan ubi kayu sangat dipengaruhi oleh keterampilan sumber daya manusia, pengalaman dan peralatan produksi yang sesuai.
\end{abstract}

Kata kunci: efisiensi, frontier, pedesaan, ubi kayu, UMKM

${ }^{1}$ Corresponding author:

Email: fitriani@polinela.ac.id 


\section{INTRODUCTION}

Small Medium Enterprises (SMEs) play a central role in the structure of the Indonesian economy. In 2019, SMEs were able to absorb $116,978,631$ workers. This figure reaches $97 \%$ of the total Indonesian workforce (MSMEs and Large Units). Indonesian SMEs growth reached $64,194,057$ units or $99.99 \%$ of the entire business units in Indonesia. Furthermore, MSMEs contribute $60.3 \%$ of Indonesia's real gross domestic product (GDP) (BPS Indonesia 2019). SMEs mostly concentratein Java (2,49 millionunit/29,33\%), Sumatera (729 thousand/8,5\%), and Bali (377 thousand/ 4,4\%) (BPS 2018). The development of SMEs in Indonesia depends on the factors that drive progress. The main factors that drive the growth of MSMEs in Indonesia include technology, information and communication facilities, and access to business capital. The existence of support from the government through various production and marketing stimuli also affects the number of MSMEs' growth rate. However, this growth is considered slow due to the effectiveness and synergy of supporting factors facing various constraints at the practical level. The most crucial problem of SMEs is a capital restriction (38.84\%) and marketing (25\%) (BPS 2018).

SME of food based on cassava has a strategic role in the rural economy. Especially in economic growth, social welfare, and employment (Mustaniroh et al. 2019; Santoso et al. 2015; Suharyono et al. 2010). It drives a considerable linkage the activity from upstream line cassava farmers, rural industries, logistic distribution, and broad marketing (Unteawati et al. 2018). Many stakeholders are involved in the cassava sector economy. Cassava consumption has driven the essential income enrichment source in rural. Cassava production and the derivation are being important income addition for farmer's households.

The sustainability of cassava processing needs support from the upstream line of fresh cassava production. Besides the staple food, cassava is an important source of feed and bio-energy (Anggraini et al. 2017; Okudoh et al. 2014; Setyowati and Maret, 2012). Indonesia's cassavaproductioncentreisprimary fromLampung, East Java, and Central Java provinces. Lampung Province contributed $34 \%$ of national cassava production than Central Java (16,9\%) and East Java (13\%). The land of cassava cultivation in Lampung contributed $27 \%$ of the total cassava land area. Lampung was the largest producer of fresh cassava reached 6,6 million tons from national production of 19,3 million tons (Kementan RI, 2019).

Cassava farmers' main problem is the low-income level due to not optimal productivity and price uncertainty. Excess supply and also because the nature of the product is easily damaged and does not last long is the leading cause. The cassava sector's constraints are driven mainly by inadequate market infrastructure, processing facilities, lack of information, and unstable prices at the local level. Therefore, most of the cassava production in Lampung faced low income and poverty problems. There were 477.03 thousand people who had income below the poverty line, with the number of unemployed 56,215 people in the three regions (BPS Lampung Province, 2015).

The cassava processing activities in rural operate in small-scale processing, categorized as small-medium enterprises (SMEs). Production determines both direct and indirect factors of production. Direct factor production is linked with raw material and workforce indirect factor related to manufactured overhead cost the production scale influences the management ability of processors to manage the production factors. The efficiency of production factor allocation will provide maximum benefit (Nursalam, 2018). The variables of credit and human resources had a positive and significant effect on marketing, and SMEs' performance (Santoso et al. 2015).

The main problem of SMEs usually lacked low productivity. The low productivity and the volatile price were caused the cassava processing in rural threaten the low income. The first lacked began from the limited access to capital and the inefficient operation, and also the quality of the product and the variants were not standardized yet. It makes the SME restricted to the broader market caused by lower pricing. Technology processing and storage incompleteness caused the operation of cassava processing to run under the capacity.

Limited access to finance support also contributed to why small processing in the rural face the complicated situation to enhance their ability and productivity - the human resources of little processing in rural becomes the most critical factor in the SME performance. The 
monetary issues and non-monetary reasons also play a more important role than financial reasons (Kurniawati and Yuliando, 2015).

Cassava processing in rural was a strategic option of income resources. The cassava sector has a broad value chain linkage, spread from local to the global value chain. The comprehension of cassava value chains analysis could contribute to poverty alleviation, enhance food security, upgrade capacity, reduce gender inequality, and improve women's participation in marketing and income control in the cassava value chains (Masamha et al. 2018). Rural cassava processing is a vital node chain in cassava value chains, especially in empowering the local business by gaining value addition and providing rural employment. The existence of cassava processing in rural contribute to women's empowerment.

Women play a dual role in contributing to household resilience in rural areas. They become a buffer for food security and agricultural household income. Women's training programs are necessary to improve cassava processing technologies and their livelihood (Asadu et al. 2014). It is required to empower rural processing through training, workshops, institutional effectiveness, product innovation, and quality.

Workshops and training will ensure suitable employment and good quality (Kusnandar et al. 2012). The training program disseminates the scientific knowledge to cassava processors should be strengthened. Processors should form a cooperative association to establish value addition centres for improved weighing and packaging methods; The extension system should focus on enhanced cassava processing technology, marketing, and profitability; improves livelihood, income, and food security of the people (Okpeke and Onyeagocha, 2015).

It is necessary to enhance the productivity of cassava processing in rural as a part of the improvement of rural livelihood. The productivity improvement could be design by introducing the innovation or technology through processing technology. Then the opportunity of the technology adoption will be applied by SMEs need to explore. This research aims to analyze the production efficiency and the level of adoption of production technology in cassava processing. Then explore the opportunity in productivity enhancement of cassava small-scale industry.

\section{METHODS}

The research location referred to the cassava production centre in Lampung starts from Central Lampung, East Lampung, Metro, Pringsewu, and Pesawaran District. Snowball sampling applied to recognizing the cassava SME in the rural started from the consumer's information in the market centre. The flow of information traced to the SMEs location settled. It involved 60 cassava SMEs as respondents. Field survey had taken from April to July 2017. Data analysis used descriptive statistical analysis and frontier production efficiency. The production function model of stochastic frontier Cobb Douglass uses as an empirical model. The frontier function model is appropriate. The model is flexible. It does not impose assumptions about the constant elasticity of production or the elasticity of substitution between inputs (Ariyanto et al. 2020; Fitri et al. 2018; Asmara et al. 2016; Hossain et al. 2015). The stochastic frontier model use as drivers of technical efficiency in cassava processing in Nigeria by (Amaza et al. 2016). Technical efficiency is set as the model of either outputoriented or input-oriented. The two-stage analytical procedure of SFP is estimating the stochastic frontier processing function and region-specific technical efficiency (TE) values for each processing firm.

$$
\operatorname{Ln} Y_{i}=\beta_{o}+\sum_{i=1}^{n} \beta_{j} \operatorname{Ln} X_{j i}+E_{i}
$$

Where: Yi (Physical production $(\mathrm{kg})$ ); X1 (material $(\mathrm{kg})$ ); X2 (machinery (IDR)); X3 (worker (man day work)); X4 (Technology adoption (dummy; $1=$ semi modern; $0=$ traditional)); $\beta$ o (Intercept); $\beta \mathrm{j}$ (Parameter coefficient); Ei (Error)

Each farmer's frontier output obtained by inputting the actual production factor into the frontier production function, i.e.:

$$
\mathrm{Qf}=\mathrm{ao}+\sum_{\mathrm{i}=1}^{\mathrm{n}} \mathrm{bj} \mathrm{Xji}
$$

The technical efficiency for each farmer calculated using the formula:

$$
\mathrm{ET}=\mathrm{Qa} / \mathrm{Qf} \times 100 \%
$$

Information: ET (Technical efficiency); Qa (Actual output); Qf (Output frontier) 
The binary logistic regression model analyzed the level of adoption in productivity enhancement. Binary logistic regression use to build a cassava SME's model adopting the new cassava processing equipment. Binary logistics is beneficial to assess the adoption and participant willingness to join the enhancement program (Guteta and Abegaz, 2016; Syaukat et al. 2014; Gibson et al. 2016). The binary equations of the logistic regression model formulated as follows:

$$
(P i)=E\left(Y=\frac{1}{X i}\right)=\frac{\theta \ln \left(\frac{P X}{1-P X}\right)}{1+\theta \ln \left(\frac{P X}{1-P X}\right)}
$$

Then the equation modified to multiple regression:

$$
\ln \left(\frac{P x}{1-P_{x}}\right)=Y t
$$

The model formulated as follow

$Y=\beta_{0}+X_{1} \beta_{1}+\beta_{2} X_{2}+\beta_{3} X_{3}+\beta_{4} X_{4}+\beta_{5} X_{5}+\beta_{6} X_{6}$

Where: PX/P1-PX (Odd ratio is the opportunities people are willing to adopt the new cassava processing equipment); $\mathrm{P}$ (xi) (Yt) (the opportunity to adopt the new cassava processing equipment on two condition $(1=$ Yes; $2=$ No) $) ; \mathrm{X} 1=($ Age (year)); X2 (Experience (year)); X3 (Education (year)); X4 (Production volume $(\mathrm{kg})) ; \mathrm{X} 5=($ Raw material quantity $(\mathrm{kg})) ; \mathrm{X} 6$ (Equipment (unit)) $\beta$ o (constant); $\beta 1$... $\beta 6$ (coefficient); $\varepsilon$ (error term).

\section{RESULTS}

Small-scale cassava processing in rural identified on the four levels based on their production capacity. Based on their minimum and maximum production capacity, the categorization of levelling the SMEs design. The lowest production was $12 \mathrm{~kg}$ per period per week. The highest was $913 \mathrm{~kg}$ per period per week. The categorical start from the home industries with production capacity maximum reached $234 \mathrm{~kg}$ per period per week. The second level was micro, with the production capacity attaint to $456 \mathrm{~kg}$ per period per week. The small level has a production capacity of around $690 \mathrm{~kg}$ per period per week.

Table 1 performed the descriptive statistic of variables. The median of the variable informed that the respondent's age was 49.5 years old. The experience of the respondent in cassava processing reached ten years. The respondent's education was ten years or equal to the first senior high school. The production volume capacity was $125 \mathrm{~kg}$. The fresh cassava, as raw material, needs $400 \mathrm{~kg}$. The cassava processing equipment unit was six types (grinder, slicer, mixer, press/jack tool, stove, scales, and steamer).

The form of cassava chips product is Klanting and cracker. Klanting produced by 17 SMEs. Cracker made by 25 SMEs. Rice analog (tiwul) multiplied by 9 SMEs. Cassava chips produced by 4 SMEs and opak 3 SMEs. The others form was modified cassava flour (mocav) (1) and tapioca flour (1). The technical efficiency value (comparison between the actual quantity and the optimum frontier production) revealed that all cassava SMEs run under inefficiency circumstances (Figure 1 and 2). As an illustration of technical efficiency, the cracker and Klanting SMEs' performance figure out. Figure 1 described the technical efficiency of cracker SMEs on average reach $61 \%$. The highest reached $87 \%$. Figure 2 exposes that Klanting SME's efficiency was lower than crackers, on average reach $54 \%$, and the highest got $81 \%$. The value was lower than $100 \%$.

Production efficiency achievement of cassava chips SMEs in rural on average was $61 \%$. The value is still less than the optimum efficiency $(100 \%)$. It means that the cassava chips SME's technical efficiency value is not efficient yet.

Input combination does not provide optimum, and technology facilities are still limited. Then caused the production output not to reach the manufactured capacity - the production run under the capacity production. Scale-up the production capacity is necessary. The main factors causing the inefficiency of cassava SMEs are a mastery of technical skills and the low managerial capability of business actors (Amaza et al. 2016; Rahman and Awerije, 2016).

Besides the optimum combination of input production, the one option to enhance the capacity production is to fulfil the technology equipment. The opportunity to adopt the new cassava processing equipment set as the binary logistic regression model. The model of smallscale cassava industry in adopting the new cassava processing equipment influenced by $\mathrm{X} 1=$ Age (year); $\mathrm{X} 2=$ Experience (year); X3= Education (year); X4= Production volume $(\mathrm{kg})$; $\mathrm{X} 5=$ Raw material quantity $(\mathrm{kg}) ; \mathrm{X} 6=$ Equipment (unit). $\mathrm{Y}$ as binary choice 
represented the opportunity to adopt the new cassava processing equipment by SMEs on two conditions (1 $=$ Yes; $2=$ No).

The binary logistic regression operated with a two-step way to get the better model design. The first step of binary logistic is performed in Table 2, and the second step in Table 3.
Based on Table 2 revealed that on the first step, the information of binary regression revealed that the goodness of fit test criteria is not sufficient yet to support the model. It displayed from the low of Deviance R-square(adj) value and AIC. The best model could determine with the smallest AIC value. This condition means that the model needs to be justified to the second step by treasuring the unusual observation. The unusual observation could influence the goodness of the model-the diagnostics for unusual observation displayed in Table 3.

Table 1. Descriptive statistic of variable

\begin{tabular}{lcccccccc}
\hline Variable & $\mathrm{N}$ & Mean & SE Mean & StDev & Variance & Min & Median & Max \\
\hline X1= Age (year) & 60 & 46.97 & 1.27 & 9.86 & 97.15 & 27.00 & 49.50 & 70.00 \\
X2 = Experience (year) & 60 & 14.65 & 1.52 & 11.81 & 139.45 & 1.00 & 10.00 & 40.00 \\
X3 = Education (year) & 60 & 7.52 & 0.38 & 2.91 & 8.46 & 3.00 & 6.00 & 15.00 \\
X4= Production volume (kg) & 60 & 2050 & 1847 & 14305 & 204637102 & 12 & 125 & 111000 \\
X5= Raw material quantity (kg) & 60 & 912 & 332 & 2570 & 6606730 & 25 & 400 & 20000 \\
X6= Equipment (unit) & 60 & 5.67 & 0.26 & 2.04 & 4.16 & 1.00 & 6.0 & 9.00 \\
Y= Production (kg) & 60 & 0.40 & 0.06 & 0.49 & 0.24 & 0.00 & 0.00 & 1.00 \\
\hline
\end{tabular}

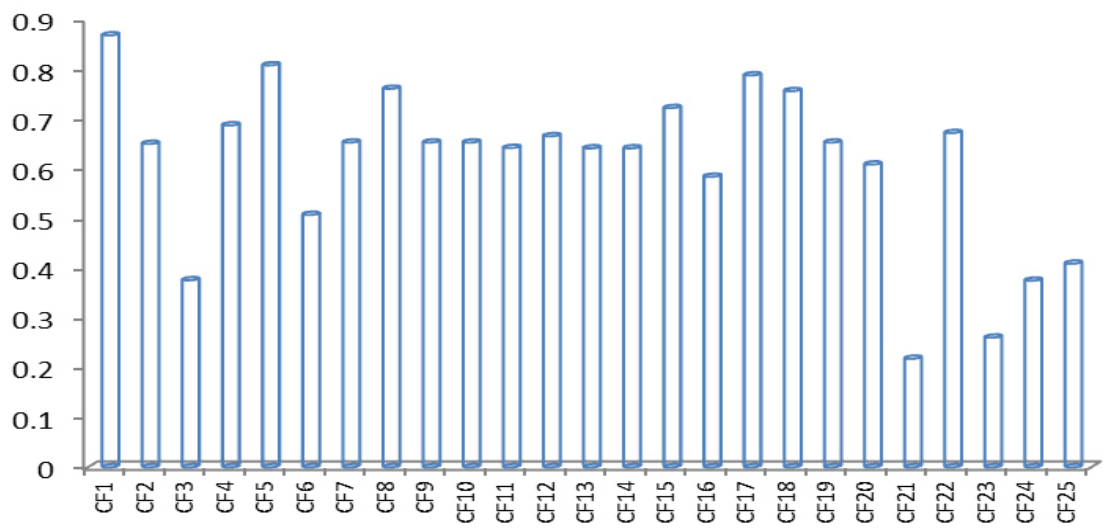

Figure 1. Technical efficiency of cassava cracker SMEs

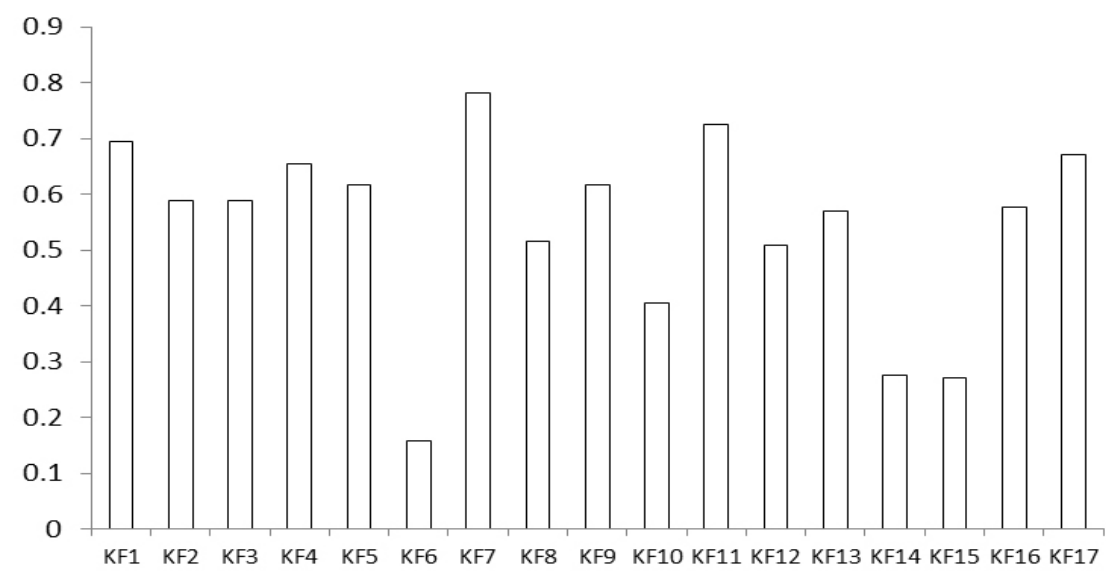

Figure 2. Technical efficiency of Klanting SMEs 
Table 2. The logistic regression analysis result (First Step)

\begin{tabular}{lccccc}
\hline Source & DF & Adj Dev & Adj Mean & Chi-Square & P-Value \\
\hline Regression & 6 & 12.0952 & 2.01586 & 12.10 & 0.060 \\
X1 & 1 & 0.5062 & 0.50622 & 0.51 & 0.477 \\
X2 & 1 & 2.8004 & 2.80042 & 2.80 & $0.094^{* *}$ \\
X3 & 1 & 0.0650 & 0.06499 & 0.06 & 0.799 \\
X4 & 1 & 0.0651 & 0.06514 & 0.07 & 0.799 \\
X5 & 1 & 0.0827 & 0.08268 & 0.08 & 0.774 \\
X6 & 1 & 9.3816 & 9.38164 & 9.38 & $0.002^{* * *}$ \\
\hline Error & 53 & 68.6662 & 1.29559 & & \\
\hline Total & 59 & 80.7614 & & & \\
Deviance & Deviance & & & & \\
R-Sq & R-Sq(adj) & AIC & & & \\
$14.98 \%$ & $7.55 \%$ & 82.67 & & & \\
\hline
\end{tabular}

**) significant at $\alpha 10 \% ; * * *$ ) significant at $\alpha 1 \%$

Table 3. The diagnostics for unusual observation (second step)

\begin{tabular}{cccccc}
\hline Obs & Observed Probability & Fit & Resid & Std Resid & \\
\hline 3 & 1.000 & 0.102 & 2.139 & 2.21 & R (Large residual) \\
15 & 1.000 & 0.111 & 2.098 & 2.19 & R (Large residual) \\
21 & 0.000 & 0.816 & -1.840 & -2.03 & R (Large residual) \\
51 & 1.000 & 0.997 & 0.081 & 1.23 & X (Unusual X) \\
\hline
\end{tabular}

Table 3 performed that in the second step appear four number of SME firm as an observed probability. Three samples categorized as large residual and one as unusual observation. The sampling of SMEs firm number 51 was shown as a unique observation. After the clearance of unusual observation (sample number 51), the second step of binary is displayed in Table 4 .

The analysis performed in Table 4 informed that the SMEs model of technology adoption the new processing equipment has the P-value of Hosmer-Lemeshow was lower than 0.05 (0.008). Hosmer-Lemeshow test is the most widely used logistic regression model (Nezic et al. 2013; Zhang, 2016) rather than the R2 value. It is based on dividing the sample up according to their predicted probabilities or risks. When the model is correctly specified, the model fitted. The p-value can be calculated as the right-hand tail probability of the corresponding chi-squared distribution using the calculated test statistic. The p-value calculation was 0,035 , which means from 1,000 simulations, the Hosmer-Lemeshow test gave a significant p-value, indicating poor fit, on $8 \%$ of occasions. Then it seems the model has the goodness of fit test and to be working ok. The model summary showed in Table 5.
The second step results better fulfilled the goodness of fit test. The value of R-Square also higher from the first, and the AIC value was lower than before. The result showed that the variables X2 (Experience) and X6 (Equipment) should be a concern as the determinant on the opportunity of SMEs adopting the new technology processing equipment. The Odd-Value of the X2 (Experience) and X6 (Equipment) were 1.05 and 1.7. The Odd-ratio value was beneficial to informed that SMEs' opportunity in adopting the new technology of processing cassava could be 1.05 and 1.7 times higher when the addition of 1 year of experience and 1-unit processing equipment.

Based on the result of the binary logistic analysis, the cassava SMEs' productivity is strongly affected by the skill of SME's human resources and technology adoption with appropriate production equipment. The research performed that cassava SMEs technology application significantly determined by experience (X2) and production equipment (X6). The Odd Ratio value of variable production equipment (X6) was 1.8. This value means that the opportunity to improve production technology will increase 1.18 times when the equipment quantity adds one unit. The Odd Ratio value of variable X2 (experience) was 1.06. It means 
that for every addition of experience time (a year), the opportunity to apply the production technology will increase 1.06 times.

The technical efficiency value indicates that the operation production of cassava SME's processing runs under optimum capacity. Inefficiency occurred when the input allocation does not gain output enhancement higher or equal. In this situation, SMEs should consider less their input and improve the combination and optimize the output. In case the SMEs run under the inefficiency circumstantial it crucial to lessening input factors and maximizing output factors (Manongga, 2014), (Fitriani and Zaini, 2012) (Fitriani et al. 2010). Enhancement the productivity could conduct by implementing the new processing technology.

SMEs' technical efficiency could be trough by improving their efficiency by processors of cassava, appropriate capital/machinery, electricity/power sources at reasonable prices, supervised credit, applicable skills, and entrepreneurship development, mainly (Dzever et al. 2016). They were strengthening the entrepreneurial characteristics and competencies of MSME actors through training and mentoring and a follow-up to improve the performance of MSMEs (Dhamayantie and Fauzan, 2017). Entrepreneurship can refer to as innovation-driven entrepreneurship the creation of "innovation-driven enterprises" (IDEs). The notion of being innovation-driven is critical as it emphasizes the entrepreneur's awareness of the need to build competitive advantage, which for an entrepreneur can only be done by taking today's resources and doing something distinctive with them. Innovation can come in many varieties, including technology, process, business model, and more (Aulet and Murray 2013). Creating competitive advantages and new markets is among the main reasons European SMEs take action (Rizos et al. 2016). Cassava processing needs to be upgraded into primary industries such as starch, ethanol, chips, and flour to provide an industrial base for further diversification of its national economy (Dada, 2016).

Table 4. Binary logistic model of SMEs adoption the new processing equipment

\begin{tabular}{lccccc}
\hline \multicolumn{1}{c}{ Source } & DF & Adj Dev & Adj Mean & Chi-Square & P-Value \\
\hline Regression & 2 & 9.669 & 4.834 & 9.67 & 0.008 \\
Experience & 1 & 2.569 & 2.569 & 2.57 & 0.109 \\
Production Equipment & 1 & 9.663 & 9.663 & 9.66 & 0.002 \\
\hline Error & 56 & 69.234 & 1.236 & & \\
\hline Total & 58 & 78.903 & & & \\
\hline
\end{tabular}

Tabel 5. Model Summary of binary logistic regression

\begin{tabular}{|c|c|c|c|}
\hline Deviance & & & \\
\hline $\mathrm{R}-\mathrm{Sq}$ & Deviance R-Sq(adj) & $\mathrm{AIC}$ & \\
\hline $12.25 \%$ & $9.72 \%$ & 75.23 & \\
\hline \multicolumn{4}{|l|}{ Coefficients } \\
\hline Term & Coef & SE Coef & VIF \\
\hline Constant & -4.29 & 1.48 & \\
\hline Experience & 0.0473 & 0.0301 & 1.55 \\
\hline Production Equipment & 0.536 & 0.191 & 1.55 \\
\hline \multicolumn{4}{|c|}{ Odds Ratios for Continuous Predictors } \\
\hline & Odds Ratio & $95 \% \mathrm{CI}$ & \\
\hline Experience & 1.0484 & $(0.9884,1.1121)$ & \\
\hline Production Equipment & 1.7093 & $(1.1767,2.4831)$ & \\
\hline
\end{tabular}

Regression Equation

$\begin{array}{lll}\mathrm{P}(1) & = & \exp \left(\mathrm{Y}^{\prime}\right) /\left(1+\exp \left(\mathrm{Y}^{\prime}\right)\right) \\ \mathrm{Y}^{\prime} & = & -4,29+0.0473 \operatorname{Exp}+1,7093 \text { Equip }\end{array}$ 
Technology adoption could enhance productivity and change the production function. Technology production techniques also improve the productivity of goods. The relation between the production and the technology performed on this condition (Carnahan et al. 2010; Singh et al. 2010):

1. Adoption of the new technology could enhance the output with the same input allocation

2. The technology could be influencing the allocation of input combinations, then the same quantity of output could be produced by the less input.

3. New technology allows using feasible inputs, reduce an input, and also add it to other inputs, which can reduce costs to produce the same output

4. Better quality of labour, better technology resources, and knowledge will improve the productivity of goods. Government need to pay more attention to relationship management and cost reduction. Human resource development and quality improvement are also highly correlated with competitiveness.

5. Vertical integration could be expanded as a strategy to manage ecosystem interdependence increases over the technology life cycle.

Cassava SMEs' productivity enhancement is necessary to match the market needs, including the product differentiation and financing schemes. A similar result on the technology adoption in rural processing also noted that the training programs to learn more about improved cassava processing technologies is essential (Acemoglu and Restrepo, 2017; Leitner and Güldenberg, 2010). This will help SMEs to adopt more technologies. It also will need support from the government as a regulator. The government should be present to upgrade small and medium enterprises. Some recommendations came up, such as widespread improved tropical cassava selection technologies and investments in market and marketing infrastructure and the processing technologies (Rahman and Awerije, 2016).

The government policy must beaddressed in two aspects: first, increasing the scale of the enterprises, secondly, fostering financial inclusion for these enterprises (Rifin, 2019). Enhancement of productivity through adopting such technologies will alleviate poverty and improve their livelihood and household food security in rural (Asadu et al. 2014). The household level, as well as within small-scale cooperatives, was identified as cassava processing. It conducted a significant portion of work being done by women. The supporting institutions in the supply chain of material, training, and the provision of processing equipment need all gather as a cassava value chain. The cassava value chains will expose well the poverty, food security, upgrading capacities, and enhancing women's participation in marketing and income control in the cassava value chains (Masamha, Thebe, and Uzokwe, 2018; ACIAR, 2012; FAO, 2014).

\section{Managerial Implications}

Efforts to build MSME business sustainability are part of an integrated work that reinforces each other in a just commodity business chain. The main key that can be a trigger is the human resources of MSME actors who are entrepreneurial, innovative, and creative. The entrepreneurial characteristics of MSME actors can only be sharpened through efforts to increase managerial capacity that can develop innovations in many variations, including technology, processes, and sustainable business models. The human resources of MSMEs need to be continuously pursued to have the opportunity to adopt various technological developments from processing, marketing to business managerial capacities. Increasing managerial capabilities will lead to better quality decision-making for a sustainable business, especially in managing human resources with better technology and increasing competitive productivity. UMKM players cannot be left alone to solve their business development problems. Collaboration and alignments are needed from the government (regional and central through accelerated policy regulations and assistance), universities (research and mentoring), business players in the empowering business value chain, and IT media support is needed to improve the sustainability of MSME business.

\section{CONCLUSIONS AND RECOMMENDATIONS}

\section{Conclusions}

The production efficiency value of cassava chips SMEs achieved $61 \%$ on average. The achievement value still less than the optimum efficiency (100\%). The cassava chips SMEs still operated at a low level of technical efficiency. Input combination does not provide optimum, and technology facilities still limited caused the production output not reach the manufactured capacity the production run under the capacity production. Scale-up the production capacity 
is necessary. The introduction of the new technology equipment opens the possibilities in scale-up capacity production. The opportunity to adopt the new cassava processing equipment's strongly was affected by human resources skills and appropriate production equipment. The cassava SMEs technology application is significantly determined by experience and production equipment. Improving managerial capability will direct a better quality of decision-making for sustainable business, especially in the human resources with better technology and productivity enhancement. The development of human resource quality is a key in the competitiveness of business entities.

\section{Recommendations}

The sustainability of local MSMEs related to the chain of stakeholders can be improved as an integrated business chain and supporting institutions, especially the government as a regulator that facilitates policies in the provision of capital, technology and a wider market. Adequate capital, technology, and managerial capability are key to improving the economics of scale of SMEs. Collaboration within the SMEs community, Business, Government, and IT media will open the opportunity for sustainable SMEs empowerment. Start from channelled the SMEs to the current microcredit scheme, product development based on market preference, broader the market share with e-commerce in market chain distribution. University and research agencies should be part of SMEs to improve technology processing adoption and human source development.

\section{ACKNOWLEDGMENT}

This research had funded by the Ministry of Research, Technology, and Higher Education. Special thanks to Nuni Anggraeni and Clara Yolandika who help infield data processing, and also JMA reviewers who give worthy advice for enhancing the quality of the manuscript.

\section{REFERENCES}

Acemoglu D, Pascual R. 2017. The race between machine and man. American Economic Review 108 (6): 1488-1542.

ACIAR. 2012. Membuat Rantai Nilai Lebih Berpihak Pada Kaum Miskin: Buku Pegangan Bagi
Praktisi Analisis Rantai Nilai. Canbera: Australian Centre for International Agricultural Research (ACIAR).

Amaza PS, Abbas AB, Bachwenkiz B, Towo EE. 2016. Adoption of mechanized postharvest cassava processing technologies, and the determinan of High Quality Cassava Flour (HQCF) Processing in Tanzania. Tropicultura 34 (September): 41123.

Anggraini N, Harianto, Lukytawati A. 2017. Analisis pendapatan dan faktor produksi usahatani ubikayu berdasarkan pasar yang dipilih petani (study kasus petani di Kabupaten Lampung Tengah). JoFSA (Journal of Food System and Agribusiness 1 (1): 12-20.

Ariyanto A, Yusman S, Sri H, Bonar MS. 2020. Technology adoption and technical efficiency of oil palm smallholder plantation in Riau and West Kalimantan. Jurnal Manajemen dan Agribisnis 17 (3): 239-53. https://doi.org/10.17358/ jma.17.3.239.

Asadu AN, Agwu AE, Chah JM, Enwelu IA. 2014. Factors influencing adoption of improved cassava processing technologies by rural women in Enugu State, Nigeria. International Journal of Agricultural Science, Research and Technology in Extension and Education Systems 4 (4): 20510.

Asmara A, Yeti LP, Deni L. 2016. Keragaan produksi susu dan efisiensi usaha peternakan sapi perah rakyat di Indonesia. Jurnal Manajemen dan Agribisnis 13 (1): 14-25. https://doi. org/10.17358/jma.13.1.14.

Aulet W, Fiona EM. 2013. A tale of two entrepreneurs: understanding differences in the types of entrepreneurship in the economy. SSRN Electronic Journal. https://doi.org/10.2139/ ssrn.2259740.

BPS. 2018. Profil Industri Mikro Dan Kecil 2018. Survei Industri Mikro Dan Kecil. Jakarta: BPS.

BPS Indonesia. 2019. Survei Industri Mikro Dan Kecil. BPS Indonesia. Jakarta: BPS-Statistics Indonesia.

Carnahan S, Rajshree A, Benjamin C. 2010. The effect of firm compensation structures on the mobility and entrepreneurship of extreme performers. Business 333 (May 2008): 1-43. https://doi. org $/ 10.1002 / \mathrm{smj}$.

Dada AD. 2016. Taking local industry to global market: the case for nigerian cassava processing companies. IISTE 7 (19): 2222-1700. 
Dhamayantie E, Rizky F 2017. Penguatan karakteristik dan kompetensi kewirausahaan untuk meningkatkan kinerja Umkm. Matrik: Jurnal Manajemen, Strategi Bisnis Dan Kewirausahaan 11 (1): 80-91. https://doi.org/10.24843/ matrik:jmbk.2017.v11.i01.p07.

Dzever D et al. 2016. Technical efficiency among small and medium scale entrepreneurs in high quality cassava flour in four geo-political zones of Nigeria. International Journal of Economics 1 (2): 16-30.

FAO. 2014. Developing Sustainable Food Value Chains - Guiding Principles. US: Food and Agriculture Organization of the United Nations (FAO). www. fao.org/publications.

Fitri A, Harianto H, Ratna WA. 2018. The effects of partnerships on the efficiency of mustard farming at Megamendung district. Jurnal Manajemen dan Agribisnis 15 (1): 12-22. https://doi. org/10.17358/jma.15.1.12.

Fitriani, Bustanul A, Hanung I. 2010. Analisis skala ekonomi produksi tebu di Propinsi Lampung. PANGAN 19 (4): 303-15.

Fitriani, Muhammad Z. 2012. Efficiency of economics of catfish growing business. Jurnal Ilmiah ESAI $6(2)$.

Gibson JM, Rigby D, Polya DA, Russell N. 2016. Discrete choice experiments in developing countries: willingness to pay versus willingness to work. Environmental and Resource Economics 65 (4): 697-721. https://doi.org/10.1007/s10640015-9919-8.

Guteta D, Assefa A. 2016. Factors influencing scaling up of agroforestry-based spatial land-use integration for soil fertility management in arsamma watershed, southwestern ethiopian highlands. Journal of Environmental Planning and Management 59 (10): 1795-1812. https:// doi.org/10.1080/09640568.2015.1090960.

Hossain M, Asraful A, Kamal U. 2015. Application of stochastic frontier production function on small banana growers of kushtia district in Bangladesh. Journal of Statistics Applications \& Probability 342 (2): 337-42.

Kementan RI. 2019. Produksi Ubikayu Menurut Propinsi 2014-2018. Kementan RI. Jakarta: Kementan RI.

KurniawatiD, Henry Y.2015. Productivity improvement of small scale medium enterprises (SMEs) on food products: case at Yogyakarta Province, Indonesia. Agriculture and Agricultural Science
Procedia 3: 189-94. https://doi.org/10.1016/j. aaspro.2015.01.037.

Kusnandar, Bekti WU, Sapja A. 2012. Rekayasa model aliansi strategis agroindustri skala kecil (kasus kluster industri tahu). SEPA 9 (1): 74-82.

Leitner KH, Stefan G. 2010. Generic strategies and firm performance in smes: a longitudinal study of Austrian SMEs. Small Business Economics 35 (2): 169-89. https://doi.org/10.1007/s11187009-9239-х.

Manongga D. 2014. Efficiency of small-and mediumsized tofu enterprises (SME) in Salatiga Using data envelopment analysis (DEA). International Journal of Computer Applications 91 (12): 975 8887.

Masamha B, Vusilizwe T, Veronica NEU. 2018. Mapping cassava food value chains in tanzania's smallholder farming sector: the implications of intra-household gender dynamics. Journal of Rural Studies 58 (December 2016): 82-92. https://doi.org/10.1016/j.jrurstud.2017.12.011.

Mustaniroh SA, Jaya MM, Ninda AP. 2019. The strategy for improvement of 'enting geti' quality in production process with fuzzy analytical hierarchy process in Blitar Regency, East Java. Jurnal Manajemen dan Agribisnis 16 (1): 97 109. https://doi.org/10.17358/jma.16.1.97.

Nezic D, Milorad B, Tatjana S, Petar V. 2013. Calibration of the euroscore ii risk stratification model: is the hosmer-lemeshow test acceptable any more? European Journal of Cardio-Thoracic Surgery : Official Journal of the European Association for Cardio-Thoracic Surgery 43 (1): 206. https:// doi.org/10.1093/ejcts/ezs346.

Nursalam N. 2018. Analyzing the efficient allocation of sago processing business production factors in east kolaka district. Indonesian Journal of Business and Entrepreneurship 4 (1): 45-54. https://doi.org/10.17358/ijbe.4.1.45.

Okpeke MY, Onyeagocha SUO. 2015. Analysis of processing cassava tubers into garri in Isoko. European Journal of Agriculture and Forestry Research 3 (5): 15-25.

Okudoh V, Cristina T, Tilahun W, Stefan S. 2014. The potential of cassava biomass and applicable technologies for sustainable biogas production in south africa: a review. Renewable and Sustainable Energy Reviews 39: 1035-52. https://doi.org/10.1016/j.rser.2014.07.142.

Rahman S, Brodrick OA. 2016. Exploring the potential of cassava in promoting agricultural growth 
in Nigeria. Journal of Agriculture and Rural Development in the Tropics and Subtropics 117 (1): 149-63.

Rifin A. 2019. Determinants of micro and small enterprise food industry market expansion in Indonesia. Indonesian Journal of Business and Entrepreneurship 5 (3): 215-22. https://doi. org/10.17358/ijbe.5.3.215.

Rizos V et al. 2016. Implementation of circular economy business models by small and mediumsized enterprises (SMEs): Barriers and Enablers. Sustainability (Switzerland) 8 (11). https://doi. org/10.3390/su8111212.

Santoso I, Desty Y, Siti AM. 2015. Pengaruh kredit dan sumber daya manusia terhadap kinerja UMKM Agroindustri Dengan Pemasaran Sebagai Variabel Antara. Jurnal Manajemen Dan Agribisnis 12 (3): 174-82. https://doi. org/10.17358/jma.12.3.174.

Setyowati N. 2012. Analisis potensi agroindustri olahan singkong di Kabupaten Bojonegoro. Jurnal Inovasi Dan Kewirausahaan 1 (3): 179-85.

Singh RK, Suresh KG, Deshmukh SG. 2010. The competitiveness of smes in a globalized economy: observations from China and India. Management Research Review 33 (1): 54-65. https://doi.org/10.1108/01409171011011562.

Suharyono MH, Setiadi D, Hartoyo. 2010. Analisis kapabilitas organisasi dan lingkungan usaha terhadap kinerja bisnis dan implikasinya bagi pengembnagan usaha di pasar tradisional spesifik PD Pasar Jaya. Jurnal Manajemen and Agribisnis 7 (1): 27-47.

Syaukat Y, Fitria NA, Fahma M. 2014. Economc value and service fee of irrigation water in The Dictrict Bogor and Kudus, Indonesia. ISSAAS 20 (2): 157-72.

Unteawati B, Fitriani, Cholid F. 2018. Consumer's Market Analysis of Product Cassava. In International Conference on Biomass: Toward Sustainable Biomass Utilization for Industrial and Energy Applications, 1-11. IOP Conference Series: Earth and Environmental Science.

Zhang Z. 2016. Model building strategy for logistic regression: purposeful selection. Annals of Translational Medicine 4 (6): 4-10. https://doi. org/10.21037/atm.2016.02.15. 